SYARIKAT : Jurnal Rumpun Ekonomi Syariah Volume 1 Nomor 2, Desember 2018

\title{
PENGARUH BAURAN PROMOSI TERHADAP PENINGKATAN JUMLAH JAMAAH UMROH PADA PT. ARMINAREKA PERDANA PERWAKILAN PEKANBARU
}

\author{
Lolyta Permata* \\ *Fakultas Agama Islam (FAI) Universitas Islam Riau (UIR) Pekanbaru \\ Jl. Kaharuddin Nasution No. 113 Perhentian Marpoyan Pekanbaru 28284 \\ e-mail: lolytapermata10@gmail.com
}

\begin{abstract}
Abstrak: Penelitian ini dilatarbelakangi banyaknya jumlah jamaah haji dan umroh dalam suatu biro haji dan umroh hal ini menjadi faktor yang sangat penting, maka untuk mencapai hal tersebut dibutuhkan promosi yang dapat meningkatkan jumlah jamaahnya. Pada dasarnya suatu promosi dilakukan untuk menyampaikan sesuatu. Promosi digunakan agar dapat mengubah cara pandang dan sikap orang lain terhadap sesuatu, Begitu juga dengan PT. Arminareka Perdana Perwakilan Pekanbaru. Adapun perumusan masalah dalam penelitian ini adalah bagaimana Pengaruh bauran promosi terhadap peningkatan jumlah jamaah. Tujuan penelitian ini untuk mengetahui pengaruh bauran promosi terhadap peningkatan jumlah jamaah umroh. Subjek dalam penelitian ini adalah jamaah umroh PT. Armina reka Perdana Perwakilan Pekanbaru yang berjumlah 96 orang. Hasil penelitian ini diketahui hubungan bauran promosi terhadap peningkatan jumlah jamaah yang memiliki hubungan kuat, ini diketahui dari nilai koefesien korelasi sebesar 93,3\%. Sedangkan hasil uji parsial terdapat pengaruh yang signifikan antara bauran promosi terhadap peningkatan jumlah jamaah, ini diketahui dari t hitung sebesar 25,071. Kemudian terdapat kontribusi yang cukup besar antara bauran promosi terhadap peningkatan jumlah jamaah, ini diketahui besaran nilai koefesien determinasi sebesar 87\%. Secara umum dapat disimpulkan bahwa Pengaruh bauran promosi terhadap peningkatan jumlah jamaah PT. Arminareka Perdana PerwakilanPekanbaru sangat tinggi.
\end{abstract}

Kata Kunci: Bauran Promosi, Peningkatan Jumlah Jamaah, Umroh

SYARIKAT : Jurnal Rumpun Ekonomi Syariah Volume 1, Nomor 2, Desember 2018 


\section{PENDAHULUAN}

Haji dan umroh pada hakekatnya merupakan aktivitas suci yang pelaksanaannya diwajibkan oleh Allah SWT kepada seluruh umat Islam yang telah mempunyai kemampuan. Disebut aktivitas suci karena seluruh rangkaian kegiatannya adalah ibadah. Haji dan umrah juga disebut sebagai ibadah puncak yang melambangkan ketaatan serta penyerahan diri secara total kepada Allah baik secara fisik material maupun spiritual. Haji dan umroh merupakan kegiatan berkunjung Baitullah, untuk mengerjakan ibadah haji dan umroh dengan cara, tempat, waktu, atau masa tertentu. Maksud dari cara tertentu tersebut adalah ihram, wukuf di arafah, thawafifadhah dan sa'i (Depag RI, 2010: 3).

Haji dan umroh dalam hal ini telah menjadi suatu fenomena yang menarik untuk dicermati, yakni apakah ibadah haji dan umroh bagi muslim Indonesia merupakan kebutuhan primer atau bukan, mengingat Indonesia merupakan mayoritas muslim terbesar didunia, sedangkan ibadah haji dan umrah merupakan ibadah yang wajib ditunaikan oleh setiap muslim yang mampu hanya sekali seumur hidupnya, namun tetap saja haji dan umroh menjadi idaman setiap muslim sehingga jumlah jamaah haji dan umroh tetap ada bahkan semakin bertambah. Bagi masyarakat Arab Saudi, haji dan umroh mungkin di anggap sebagai ibadah yang biasa saja. Namun sebagian besar kaum muslimin yang tinggal diluar wilayah Arab Saudi apalagi di negara-negara yang jauh, haji dan umroh jelas merupakan ibadah yang istimewa. Tidak hanya kesiapan mental spiritual, haji dan umroh bagi penduduk yang jauh dari Arab Saudi juga membutuhkan kesehatan fisik.

Kegiatan-kegiatan dalam penyelenggaraan haji dan umroh tersebut dilaksanakan oleh dan lembaga-lembaga lainnya yang ada kaitannya dengan penyelenggaraan urusan haji dan umroh dengan cara koordinasi interdepartemental yang dalam hal ini Menteri Agama bertindak sebagai penanggung jawab.

Tabel 1: Data Jumlah Jamaah Umroh PT. Arminareka Perdana Perwakilan Pekanbaru

\begin{tabular}{|c|c|c|}
\hline No & Tahun & Jumlah Jamaah Umrah \\
\hline 1 & 2014 & 165 Orang \\
\hline 2 & 2015 & 997 Orang \\
\hline 3 & 2016 & 2.474 Orang \\
\hline \multicolumn{2}{|c|}{ Jumlah } & $\mathbf{3 . 6 3 6}$ Orang \\
\hline
\end{tabular}

Sumber Data : Data Olahan PT. Arminareka Perdana Perwakilan Pekanbaru

Berdasarkan tabel diatas dapat dilihat terjadi peningkatan jumlah jamaah yang sangat tinggi disetiap tahunnya. Dimana ditahun pertama keberangkatan jamaah umroh berjumlah 165, ditahun
2015 jumlah jamaah berangkat umroh 997, dan ditahun 2016 jumlah jamaah yang berangkat umroh sebanyak 2.474 .

Banyaknya jumlah jamaah haji dan umroh dalam suatu biro haji dan umroh

SYARIKAT : Jurnal Rumpun Ekonomi Syariah Volume 1, Nomor 2, Desember 2018 
pun menjadi faktor yang sangat penting, maka untuk mencapai hal tersebut dibutuhkan promosi yang dapat meningkatkan jumlah jamahnya. Promosi yang berhasil adalah kegiatan yang mampu menggugah naluri ingin memiliki sesuatu produk tertentu. Dengan adanya promosi yang sesuai dengan minat para jamaah haji dan umroh, tentu akan tercipta pencitraan yang hebat, dimana jamaah akan merasa puas terhadap pelayanan juga fasilitas yang dipromosikan oleh biro perjalanan haji dan umroh. Dengan demikian, para jamaah haji dan umroh akan selalu percaya pada biro perjalanan haji dan umroh tersebut, bahkan para jamaah haji dan umroh pun tak segansegan untuk mempromosikan kepada orang lain.

Bagian promosi dalam bauran pemasaran melibatkan pemberitahuan kepada pelanggan target bahwa produk yang tepat tersedia ditempat dan pada harga yang tepat. Promosi juga harus sesuai dengan variabel-variabel lainnya dalam bauran pemasaran serta menegaskan diferensiasi dan pemposisian strategi tersebut Fandy Tjiptono (2008: 221).

Dari semua aspek bauran promosi PT. Arminareka Perdana Perwakilan Pekanbaru sudah melakukannya dalam mempromosikan PT. Arminareka Perdana Perwakilan Pekanbaru. Adapun promosi yang sudah dan yang sedang dilakukan PT. Arminareka Perdana Perwakilan Pekanbaru adalah sebagai berikut:

1. Melalaui jamah-jamaah yang telah berangkat dengan memasukan informasi kepada mereka untuk disampaikan kepada orang-orang lingkungannya (Personal Selling).

2. Pendekatan melalui seminar-seminar dengan calon jamaah (Public Relation).

3. Pembinaan satu kali seminggu dengan mitra-mitra kerja (Personal Selling).
4. Menempel kan brosur-brosur disekitar tempat lingkungan (Advertising).

5. Memasang baliho tentang prestasi PT. Arminareka Perdana Perwakilan Pekanbaru (Advertising).

6. Sosialisasi diluar daerah (Public Relation).

7. Website resmi PT. Arminareka Perdana Perwakilan Pekanbaru (Internet Markting).

Adapun sistem promosi yang akan dilakukan oleh PT. Arminareka Perdana Perwakilan Pekanbaru dalam perencanaan selanjutnya untuk mengajak calon jamaah adalah sebagai berikut:

1. Seminar UKB (Umroh dan kaya berkah)(Public Relation).

2. PK (Pengembangan Kemitraan)(Public Relation).

3. MDR (Mengejar Dikejar Reward)(Sales Promotion).

4. PPE (Pelatihan Presentasi Efektif)(Personal Selling).

5. PPR (Peltihan Percepatan Reward)(Personal Selling.)

6. PKK (Pelatihan Keberuntungan dan Kesuksesan)(Personal Selling).

7. Seminar Akbar (Syiar Akbar Baitullah)(Public Relation).

8. Milad Arminareka(Public Relation)

9. Perluasan titik seminar dari yang sebelumnya hanya ada tiga tempat rutin menjadi 23 titik rutin tempat seminar yang akan dilaksanakan(Public Relation).

10. Memberikan pelatihan pada tour leader satu kali seminggu(Personal Selling)

\section{TINJAUAN PUSTAKA \\ Promosi \\ Pengertian Promosi}

Promosi berasal dari kata promote dalam bahasa Inggris yang diartikan 
sebagai mengembangkan atau meningkatkan.

Promosi merupakan salah satu cara yang digunakan oleh perusahaan untuk mengadakan komunikasi dengan pasarnya, dengan tujuan untuk memberitahukan bahwa suatu produk itu ada dan memperkenalkan produk tersebut kepada pembeli atau calon pembeli. Promosi merupakan salah satu cara yang dibutuhkan perusahaan dalam meningkatkan volume penjualan. Oleh karena itu, kegiatan promosi ini harus dapat dilakukan sejalan dengan rencana pemasaran serta diarahkan dan dikendalikan dengan baik sehingga promosi tersebut benar-benar dapat memberikan kontribusi yang tinggi dalam upaya meningkatkan volume penjualan (Rangkuti, 2009:49).

\section{Kegiatan Promosi}

Menurut Hermawan (2012:38)

kegiatan promosi biasanya merupakan salah satu komponen yang menjadi prioritas dari kegiatan pemasaran. Dengan adanya promosi maka konsumen akan mengetahui bahwa perusahaan meluncurkan produk baru yang akan menggoda konsumen untuk melakukan kegiatan pembelian. Banyak yang mengatakan bahwa kegiatan promosi identik dengan dana yang dimiliki oleh perusahaan. Semakin besar dana yang dimiliki oleh suatu perusahaan umumnya akan menghasilkan promosi yang juga sangat gencar. Namun dana bukanlah segala-galanya. Dana yang terbatas dapat diatasi dengan inovasi yang lebih cerdas dan tepat. Salah satu solusi yang dapat dilakukan adalah dengan menganalisis keunggulan produk, modal lain yang dimiliki oleh perusahaan dan segmen pasar yang dibidik. Kegiatan promosi sangat erat kaitannya dengan penyebaran informasi untuk disampaikan ke konsumen. Dalam penyampaian informasi ini ada beberapa hal yang hendaknya diperhatikan, yaitu:

a. Program periklanan yang dijalankan.

b. Promosi dengan mengutamakan penjualan yang dilakukan secara pribadi.

c. Promosi yang dilakukan dengan mengedepankan aspek penambahan intensitas nilai produk.

d. Promosi dengan cara meningkatkan publisitas.

\section{Bauran Promosi}

Menurut Lupiyoadi (2011:120) perangkat promosi yang di kenal mencakup aktivitas periklanan, penjualan perseorangan (personal selling), promosi penjualan, hubungan masyarakat (public relation), informasi dari mulut ke mulut (word of mouth), pemasaran langsung (direct marketing). Bauran promosi antara lain:

\section{Periklanan}

Periklanan merupakan salah satu bentuk dari komunikasi impersonal yang digunakan oleh perusahaan barang atau jasa. Peranan periklanan dalam pemasaran jasa adalah untuk membangun kesadaran terhadap keberadaan jasa yang ditawarkan, menambah pengetahuan konsumen tentang jasa yang ditawarkan, membujuk calon konsumen untuk membeli atau menggunakan jasa tersebut, dan membedakan diri perusahaan lain yang mendukungpositioning jasa(Lupiyoadi, 2011:120).

Terdapat beberapa tujuan periklanan, antara lain sebagai berikut:

a. Iklan yang bersifat memberikan informasi (informative advertising), iklan yang panjang lebar menerangkan produk jasa dalam tahap perkenalan guna menciptakan permintaan atas produk tersebut. 
b. Iklan membujuk (persuasive advertising), iklan menjadi penting dalam situasi persaingan, dimana sasaran perusahaan adalah menciptakan permintaan yang selektif akan merek tertentu.

c. Iklan pengingat (reminder advertising), iklan ini akan sangat penting dalam tahap kedewasaan (maturity) suatu produk untuk menjaga agar konsumen selalu ingat akan produk tersebut.

d. Iklan pemantapan (reinforcement advertising), iklan yang berusaha meyakinkan para pembeli bahwa mereka telah mengambil pilihan yang tepat.

Pada dasarnya tujuan pengiklanan adalah komunikasi yang efektif dalam rangka mengubah sikap dan perilaku konsumen, untuk itu ada beberapa pilihan media yang dapat digunakan untuk melakukan pengiklanan, antara lain melalui: surat kabar, majalah, radio, televisi, papan reklame, surat langsung.

\section{Penjualan Perseorangan}

Penjualan perseorangan mempunyai peranan yang penting dalam pemasaran jasa karena:

a. Interaksi secara personal antara penyedia jasa dan konsumen sangat penting.

b. Jasa tersebut disediakan oleh orang bukan oleh mesin.

c. Orang merupakan bagian dari produk jasa.

\section{Promosi Penjualan}

Promosi penjualan adalah semua kegiatan yang dimaksudkan untuk meningkatkan arus barang atau jasa dari produsen sampai pada penjualan akhirnya. Promosi penjualan terdiri atas brosur, lembar informasi dan lain-lain.

Promosi penjualan dapat diberikan kepada: a. Konsumen, berupa penawaran cumacuma, sampel, demo produk, kupon, pengembalian tunai, hadiah, kontes dan garansi.

b. Perantara, berupa barang cuma-cuma, diskon, iklan kerja sama, penghargaan.

c. Tenaga penjualan, berupa bonus, penghargaan, dan hadiah untuk tenaga penjualan terbaik (Lupiyoadi, 2011:121).

\section{Hubungan Masyarakat}

Hubungan masyarakat merupakan kiat pemasaran penting lainnya, dimana perusahaan tidak hanya harus berhubungan dengan nasabah tetapi juga harus berhubungan dengan kumpulan kepentingan publik yang lebih besar (Lupiyoadi, 2011:122).

$$
\text { Hubungan masyarakat sangat }
$$
peduli terhadap beberapa tugas pemasaran, antara lain:

a. Membangun citra

b. Mendukung aktivitas komunikasi lainnya

c. Mengatasi permasalahan dan isu yang ada

d. Memperkuat positioning perusahaan

e. Memengaruhi publik yang spesifik

f. Mengadakan peluncuran untuk produk/jasa baru.

Program hubungan masyarakat, antara lain:
a. Publikasi
b. Acara-acara penting
c. Hubungan dengan investor
d. Pameran
e. Mensponsori beberapa acara

\section{Informasi dari Mulut ke Mulut}

Dalam hal ini peranan orang sangat penting dalam mempromosikan jasa. Pelanggan sangat dekat dengan penyampaian jasa, dengan kata lain pelanggan tersebut akan berbicara kepada pelanggan lain yang berpotensial tentang 
pengalamannya dalam menerima jasa tersebut, sehingga informasi dari mulut ke mulut ini sangat besar pengaruhnya dan dampaknya terhadap pemasaran jasa dibandingkan dengan aktivitas komunikasi lainnya (Lupiyoadi, 2011:121).

\section{Pemasaran langsung}

Pemasaran langsung merupakan unsur terakhir dalam bauran komunikasi dan promosi. Terdapat enam area dari pemasaran langsung sebagai berikut:

a. Direct mail adalah surat langsung secara tradisional banyak digunakan sebagai media pemasaran langsung dan pemasar langsung banyak belajar dari surat langsung. Surat langsung telah digunakan untuk menjual berbagai jenis barang dan jasa untuk konsumen dan juga bisnis.

b. Mail order atau pesanan lewat pos adalah bentuk penjualan eceran yang barangnya dikirim melalui pos atau jasa kurir.

c. Direct response adalah iklan respons langsung untuk media cetak di majalah mengajak pembaca dengan menawarkan atau menarik pembaca untuk memesan barang.

d. Direct selling atau penjualan langsung adalah cara memasarkan produk maupun jasa langsung kepada pelanggan.

e. Telemarketing adalah memasarkan jasa atau jasa usaha kita melalui telepon. Biasanya caratelemarketing ini dipakai oleh beberapa operator besar untuk menawarkan produknya.

f. Digital marketingatau pemasaran digital adalah suatu bentuk usaha mempromosikan dan memasarkan sebuah merek (brand) dengan menggunakan media digital seperti internet (Lupiyoadi, 2011:122).
Dari enam area pemasaran langsung yang telah dijelaskan diatas, PT. Arminareka Perdana Perwakilan Pekanbaru hanya menggunakan dua dari enam sistem pemasaran langsung diatas, yaitu Direct sellingdan Digital marketing.

\section{Promosi dalam Islam}

Menurut Nembah (2011: 190) pemasaran modern menutut lebih dari sekedar produk yang baik, harga yang menarik dan mudah diperoleh, tetapi perusahaan harus berkomuikasi dengan pelanggan.Komunikasi perusahaan yang disebut bauran promosi adalah campuran dari periklanan, penjualan perorangan, promosi penjualan dan hubungan masyarakat.

\section{Umroh}

Dalam kamus Besar Bahasa Indonesia, umroh adalah kunjungan (ziarah) ke tempat suci (sebagai bagian dari upacara naik haji, dilakukan setiba di Mekkah) dengan cara berihram, tawaf, sa'i, bercukur, tanpa wukuf di Padang Arafah, yang pelaksanaannya dapat bersamaan dengan waktu haji atau di luar waktu haji; haji kecil (Departemen Pendidikan Nasional RI, 2008:1526).

Umroh, dalam bahasa arab, umroh artinya ziarah. Menurut pendapat lain, umroh artinya pergi ke suatu tempat yang berpenghuni. Ibadah ini disebut umroh karena ia boleh dilaksanakan sepanjang hidup. Adapun pengertian umroh dalam istilah syariat adalah: pergi ke Ka'bah untuk menunaikan ibadah, yaitu thawaf dan sa'i. Umroh tidak bisa diwakili oleh haji meskipun haji mengandung amalan-amalan umroh (Departemen Agama RI, 2008: 23).

\section{Kedudukan Umroh dalam Islam}

Haji adalah rukun islam yang kelima. Allah mewajibkannya atas orang yang mampu. Demikian pula umroh. Kedua- 
duanya wajib menurut madzhab Syafi'i dan Hambali, berdasarkan firman Allah dalam surah al-Baqarah ayat 196:

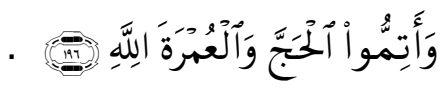

Artinya: "Dan sempurnakanlah ibadah haji dan umroh karena Allah" (Departemen Agama RI, 2008: 24).

Sedangkan menurut madzhab Maliki dan Hanafi, umroh adalah sunnah, sebagaimana akan dijelaskan nanti. Nabi SAW. Melaksanakan umroh empat kali, semuanya dalam bulan Dzulqa'dah, kecuali umrah yang dilaksanakan bersama hajinya. Umroh yang pertama beliau kerjakan dari Hudaibiyah pada tahun $6 \mathrm{H}$, setelah mengadakan perjanjian damai antara kaum muslimin dan kaum quraisy yang terkenal dengan perjanjian Hudaibiyah yang berisi lima poin penting bagi sejarah islam, dan ada pun lima poin perjanjian tersebut sebagai berikut:

1. Segala permusuhan antara kedua belah pihak dihentikan selama 10 tahun

2. Setiat orang Quraisy yang datang kepada kaum muslimin tanpa seizing walinya harus ditolak dan dikembalikan

3. Setiap orang islam yang menyerahkan diri kepada pihak Quraisy tidak akan dikembalikan

4. Setiap kabilah yang ingin bersekutu dengan kaum Quraisy maupun dengan kaum muslimin tidak boleh dihalangi oleh salah satu pihak yang membuat perjanjian ini.

5. Kaum muslimin tidak boleh memasuki mekka pada tahun ini, namun diberi kesempatan pada tahun berikutnya dengan syarat tidak membawa senjata, kecuali pedang dalam sarungnya dan tidak tinggal di mekkah lebih dari tiga hari (Siti Maryam, 2003:38).

\section{Hukum Umroh}

Menurut madzhab Hanafi dan pendapat yang paling rajih dalam madzhab Maliki, umroh itu sunnah muakad satu kali seumur hidup, karena hadist-hadist yang masyhur dan shahih menyebutka kewajiban-kewajiban dalam Islam tidak menyebutkan umroh sebagai salah satu kewajiban tersebut, misalnya hadist Ibnu Umar, "Islam itu didirikan di atas lima perkara" yang hanya menyebutkan haji saja. Jabir meriwayatkan bahwa Badui pernah menghadap Rasulullah SAW lalu berkata, "Wahai Rasulullah, apakah umroh itu wajib?"Beliau menjawab, "tidak, tapi sangat baik jika kau mengerjakan umroh".

Imam syafi'i, salah seorang pendiri madzhab, dalam kitabnya Al Umm (2013: 586), menjelaskan bahwa hukum umroh adalah wajib. Karena Allah mensejajarkan umrah dengan haji dalam firman-Nya, "Dan sempurnakanlah ibadah haji dan umroh karena Allah".Beliau lebih cenderung menggunakan zhahir ayat tersebut, tidak mentakwilkannya (interprestasi).

Para ulama madzhab Hambali meriwayatkan dari Imam Ahmad bahwa penduduk Mekkah tidak wajib melakukan umroh, dengan dalil bahwa Ibnu Abbas dulu memandang bahwa umroh itu wajib tapi dia berkata, "Wahai penduduk mekkah, kalian tidak wajib melaksanakan ibadah umroh. Umroh kalian hanyalah berthawaf di $K a$ 'bah."Pendapat ini juga diriwayatkan dari Atha', sebab rukun umroh dan amalannya yang paling besar adalah thawaf di Ka'bah, dan hal ini dilakukan penduduk Mekkah, maka itu sudah cukup bagi mereka.

\section{METODE}

Penelitian ini termasuk desain penelitin kausalitas yaitu jenis penelitian yang disusun untuk meneliti jenis kemungkinan adanya hubungan sebab

SYARIKAT : Jurnal Rumpun Ekonomi Syariah Volume 1, Nomor 2, Desember 2018 
akibat antara variabel. Penelitian ini bertujuan untuk mengetahui Pengaruh Bauran Promosi terhadap Peningkatan Jumlah Jamaah Umroh Pada PT. Arminareka Pekanbaru. Penelitian ini dilakukan di PT. Arminareka Perdana Perwakilan Pekanbaru yang beralamat di Jl. Inpres (Kartama) depan PASKHAS AURI Pekanbaru. Dalam penelitian ini yang dijadikan populasi adalah jamaah umrah yang terdata tahun 2016 sebanyak 2.474 jamaah umrah.

Dari jumlah populasi di atas, maka penulis melakukan pengambilan sampel. Untuk menentukan sampel responden dari populasi penelitian maka digunakan ketentuan dalam menentukan ukuran sampel berdasarkan pendapat Slovin dengan rumusan sebagai berikut (Anwar Sanusi, 2011: 101):

$$
n=\frac{N}{1+\left(N \times \alpha^{2}\right)}
$$

Dimana :

$$
\begin{aligned}
& \mathrm{n}=\text { Ukuran Sampel } \\
& \mathrm{N}=\text { Ukuran Populasi } \\
& \alpha=\text { Toleransi Ketidaktelitian (dalam }
\end{aligned}
$$

hal ini ditetapkan sebesar 10\%).

Berdasarkan rumusan di atas maka dapat dihitung ukuran sampel dalam penelitian ini dengan hasil perhitungan sebagai berikut :

$$
\begin{aligned}
& n=\frac{2474}{1+\left(2474 \times 10 \%^{2}\right)} \\
& n=\frac{2474}{1+\left(2474 \times 0,1^{2}\right)} \\
& n=\frac{2474}{1+(2474)} \\
& n=\frac{2474}{25,74}=96,11=96 \text { orang }
\end{aligned}
$$

Berdasarkan perhitungan di atas, maka sampel penelitian sebanyak 96 jamaah, yang nantinya akan dipilih dengan teknik pengambilan sampel menggunakan simple random sampling, yaitu pengambilan secara sampel acak sederhana dimana setiap anggota populasinya mendapatkan kesempatan yang sama untuk dijadikan sampel (Sanusi, 2011: 102).

Data yang dikumpulkan dalam penelitian ini terbagi pada dua bagian, pertama; Data Primer yaitu data-data yang diperoleh langsung dari lapangan (responden) PT. Arminareka Perdana Perwakilan Pekanbaru yang akan dikumpulkan melalui teknik sebagai berikut: Pertama, angket yaitu Penulis membuat pertanyaan secara tertulis (angket) dengan memberi alternatif jawaban untuk setiap pertanyaan, kemudian disebarkan kepada responden yang menjadi objek penelitian untuk diisi. Untuk mendapatkan data dengan cara menyebarkan sejumlah pertanyaan diajukan kepada jamaah umroh yang ada di PT. Arminareka Perdana Perwakilan Pekanbaru. Kedua, dokumentasi yaitu mengumpulkan data PT. Arminareka Perdana Perwakilan Pekanbaru.

Adapun Teknik Pengolahan Data yaitu data-data yang diperoleh dengan metode diatas kemudian diolah dengan teknik sebagai berikut :

a. Editing (penyuntingan), proses pengecekan atau memeriksa data yang telah berhasil dikumpulkan dari lapangan, karena kemungkinan data yang telah masuk tidak memenuhi syarat atau tidak dibutuhkan. Tujuan dilakukan editing adalah untuk mengoreksi kesalahan-kesalahan dan kekurangan yang terdapat pada catatan dilapangan. 
b. Codeting (pengkodean), kegiatan pemberian kode tertentu tiap-tiap data yang termasuk kategori yang sama. Kode adalah isyarat yang dibuat dalam bentuk angka-angka atau huruf untuk membedakan antara data atau identitas data yang dianalisis.

c. Tabulating (pentabulasian), proses penempatan data kedalam bentuk table yang telah diberi kode sesuai dengan kebutuhan analisis. Tabel-tabel yang dibuat sebaiknya mampu meringkas agar memudahkan dalam proses analisis data (Siregar, 2012 : 86)

\section{Teknik Analisis Data}

Analisis data yang digunakan dalam penelitian ini adalah metode diskriptif kuantitatif yaitu menganalisa data secara argumen berdasarkan data dan menganalisa data secara statistik dengan menggunakan analisi regresi sederhana yaitu mengukur pengaruh antara variabel $\mathrm{X}$ terhadap variabel $\mathrm{Y}$ dan datanya menggunakan komputer program SPSS Versi 17.0.

$$
\text { Variabel penelitian yang }
$$
mempengaruhi Bauran Promosi terhadap peningkatan jumlah jamaah umroh pada PT. Arminareka Perdana Perwakilan Pekanbaru diberikan menggunakan skala likert yang terdiri dari lima pilihan jawaban yaitu:

$\begin{array}{lll}\text { Sangat Setuju (SS) } & = & 5 \\ \text { Setuju (ST) } & = & 4 \\ \text { Netral (N) } & = & 3 \\ \text { Tidak Setuju (TS) } & = & 2 \\ \text { Sangat Tidak Setuju (STS) } & = & 1\end{array}$

\section{Uji Hipotesis}

\section{Persamaan Regresi Sederhana}

Analisis regresi sederhana adalah regresi linier sederhana terdiri atas dua variabel. Satu variabel yang berupa variabel terikat/ tergantung diberi simbol Y dan variabel kedua yang berupa variabel bebas diberi simbol X. Regresi sederhana ini menyatakan hubungan kausalitas antara dua variabel dan memperkirakan nilai variabel terikat berdasarkan nilai variabel bebas. Persamaan yang dipergunakan untuk memprediksi nilai variabel Y disebut dengan persamaan regresi (Sanusi, 2014: 131).

Analisa ini digunakan untuk mengetahui atau mengukur pengaruh antara bauran promosi terhadap peningkatan jumlah jamaah yang dinyatakan dalam bentuk persamaan matematik.

$\mathrm{Y}=\mathrm{a}+\mathrm{bX}$

Keterangan :

$\mathrm{X}=$ Bauran Promosi

$\mathrm{Y}=$ Peningkatan jumlah jamaah

$\mathrm{a}=$ Konstanta

$\mathrm{b}=$ Koefisien Regresi.

\section{Uji Parsial ( Uji t)}

Menurut Hartono (2006: 127) Uji t digunakan untuk mencari nilai korelasi murni yang terlepas dari pengaruhpengaruh variabel lain.

Langkah-langkahnya sebagai berikut:

a. Merumuskan Hipotesis

b. Menentukan level of siqnificance $\alpha=$ 0,005

c. Kriteria pengujian adalah jika $t$ tabel $\leq t$ hitung,$\leq \mathrm{t}$ tabel, maka Ho diterima dan Ha ditolak. Jika $t_{\text {hitung }}>\mathrm{t}$ tabel, maka Ho ditolak dan Ha diterima (Sanusi, 2014: 138).

\section{Koefisiensi Korelasi}

Kegunaan untuk mengetahui derajat hubungan dan kontribusi variabel bebas dengan variabel terikat maka digunakan koefisien korelasi (Sanusi, 2014 : 151). 
Tabel 5: Interprestasi Koefisiensi Korelasi

\begin{tabular}{|c|c|}
\hline Interval Koefisien & Tingkat Hubungan \\
\hline $0,00-0,199$ & Sangat Rendah \\
\hline $0,20-0,399$ & Rendah \\
\hline $0,40-0,599$ & Sedang \\
\hline $0,60-0,799$ & Kuat \\
\hline $0,80-1,000$ & Sangat Kuat \\
\hline
\end{tabular}

Sumber Data: Riduwan Sunarto (2014:81)

\section{Koefisiensi Determinasi}

Untuk mengukur besarnya kontribusi variabel $\mathrm{X}$ terhadap variabel $\mathrm{Y}$ digunakan uji keofisen determinasi berganda $\left(R^{2}\right)$. Koefisien determinasis $\left(\mathrm{r}^{2}\right)$ adalah besaran yang menunjukkan seberapa besar perubahan variabel terikat (Y) yang dapat depengaruhi oleh varibel bebas (X) (Riduwan 2010: 81).
HASIL

Analisis Data

Analisis Regresi Sederhana

Hasil perhitungan analisis regresi sederhana melalui SPSS For Windows Versi 17.0, maka diperoleh nilai-nilai untuk variabel bebas dan variabel terikat dapat dilihat pada tabel berikut :

\section{Tabel 14: Hasil Uji Analisis Regresi Sederhana}

\begin{tabular}{|r|r|r|r|rr|}
\hline \multicolumn{2}{|l|}{$\begin{array}{l}\text { Unstandardized } \\
\text { Coefficients }\end{array}$} & $\begin{array}{l}\text { Standardized } \\
\text { Coefficients }\end{array}$ & \multicolumn{2}{|r|}{} \\
\hline \multicolumn{1}{|c|}{ B } & Std. Error & \multicolumn{1}{|c|}{ Beta } & t & \multicolumn{2}{|c|}{ Sig. } \\
\hline 7,667 & 2,568 & & 2,986 & 0,004 \\
0,790 & 0,032 & 0,933 & 25,071 & 0,000 \\
\hline
\end{tabular}

Sumber: Data Olahan SPSS Versi 17.0

Bentuk umum dari persamaan regresi dinyatakan dengan persamaan matematika, yaitu:

$$
\hat{Y}=a+b X
$$

$\hat{Y}=7,667+0,790 X$

Arti angka-angka dalam persamaan regresi di atas adalah:

1) Nilai $a=7,667$ menunjukkan bahwa apabila nilai $X=0$, maka nilai variabel $Y$ sebesar 7,667.

2) Nilai $b=0,790$ menunjukkan bahawa apabila nilai variabel bauran promosi (X) meningkat sebesar satu- satuan maka variabel minat jamaah (Y) akan mengalami peningkatan sebesar 0,790 satuan dengan asumsi variabel X tetap atau konsisten.

\section{Uji-t (Uji Parsial)}

Uji-t dilakukan untuk melihat pengaruh masing-masing variabel, yaitu variabel bebas dan variabel terikat dengan menggunakan Uji-t (Uji Parsial) dengan menggunakan bantuan komputer program SPSS For Windows Versi 17.0, maka Uji-t dapat dilihat pada tabel berikut:

SYARIKAT : Jurnal Rumpun Ekonomi Syariah Volume 1, Nomor 2, Desember 2018 
Tabel 15: Hasil Perhitungan Uji-t

\begin{tabular}{|c|c|c|c|c|c|}
\hline \multirow[b]{2}{*}{ Model } & \multicolumn{2}{|c|}{$\begin{array}{l}\text { Unstandardized } \\
\text { Coefficients }\end{array}$} & \multirow{2}{*}{$\begin{array}{c}\begin{array}{c}\text { Standardize } \\
\mathrm{d} \\
\text { Coefficients }\end{array} \\
\text { Beta }\end{array}$} & \multirow[b]{2}{*}{$\mathrm{t}$} & \multirow[b]{2}{*}{ Sig. } \\
\hline & B & Std. Error & & & \\
\hline 1 (Constant) & 7,667 & 2,568 & & 2,986 & 0,004 \\
\hline Promosi & 0,790 & ,032 & 0,933 & 25,071 & 0,000 \\
\hline
\end{tabular}

Sumber: Data Olahan SPSS Versi 17.0

Dari pengolahan tabel di atas dapat diketahui bahwa nilai $t$ hitung variabel bauran promosi (X) sebesar 25,071 dan nilai t tabel di dapat dari $\mathrm{dk}=\mathrm{n}-2$, maka $\mathrm{dk}$ $=96-2=94$. Dengan taraf signifikan sebesar 0.05 (5\%) maka $t$ tabel adalah 1,661 , maka terlihat bahwa $t_{\text {hitung }}>\mathrm{t}_{\text {tabelatau }}$ 25,071> 1,661, maka Ha di terima dan Ho ditolak,sehingga dapat dikatakanterdapat pengaruhyang signifikan antara bauran promosi terhadap peningkatan jumlah jamaah umroh di PT. Arminareka Perdana Perwakilan Pekanbaru.

\section{Koefisien Korelasi}

Koefisien korelasi berfungsi untuk melihat kuat lemahnya pengaruh antara variabel bebas terhadap variabel terkat. Untuk mengetahui hal tersebut, maka dapat digunakan koefisien korelasi dengan menggunakan bantuan komputer program SPSS FOR Windows Versi 17.0, dan hasilnya dapat dilihat pada tabel berikut:

Tabel 16: Analisis Korelasi

\begin{tabular}{|l|r|r|r|r|}
\hline Model & \multicolumn{1}{|c|}{$\mathrm{R}$} & \multicolumn{1}{|c|}{ R Square } & Adjusted R Square & Std. Error of the Estimate \\
\hline 1 & $0.933^{\mathrm{a}}$ & 0.870 & 0.869 & 2.829 \\
\hline
\end{tabular}

Sumber: Data Olahan SPSS Versi 17.0

Dari pengolahan tabel di atas dapat diketahui bahwa nilai $\mathrm{R}$ menunjukkan korelasi antara variabel independen dengan variabel dependen. Diketahui nilai R sebesar 0,933 atau 93,3\%. Berdasarkan tabel interval koefisien dengan tingkat hubungan, maka KK berada pada $0,70<\mathrm{KK}<0,90$, yang berarti interpretasi koefisien korelasinya kuat atau tinggi.

Uji Koefisien Determinasi

Sedangkan untuk melihat besarnya kontribusi variabel $\mathrm{X}$ terhadap Y dilihat dari

koefisien determinasi. Koefisien Determinasi (R) adalah menunjukkan seberapa besar perubahan variabel terikat (Y) yang dapat dipengaruhi oleh variabel bebas $(\mathrm{X})$.

Diketahui nilai $R$ Square sebesar $87 \%$, artinya variabel $\mathrm{X}$ (bauran promosi) memiliki pengaruh $87 \%$ terhadap variabel Y (peningkatan jumlah jamaah) dan 13\% lainnya dipengaruhi oleh faktor-faktor lain diluar variabel $\mathrm{X}$ yaitu periklanan, penjualan perseorangan, hubungan

SYARIKAT : Jurnal Rumpun Ekonomi Syariah Volume 1, Nomor 2, Desember 2018 
masyarakat, informasi dari mulut kemulut, dan pemasaran langsung yang merupakan dimensi lainnya dari Bauran Promosi.

\section{PEMBAHASAN}

Penelitian tentang pengaruh bauranpromosi terhadap peningkatan jumlah jamaah umroh di PT. Arminareka Perdana Perwakilan Pekanbaru terdiri dari dua variabel yaitu variabel bebas (bauran promosi) dan variabel terikat (peningkatan jumlah jamaah).

Analisis data yang digunakan dalam penelitian ini adalah metode deskriptif yaitu menganalisis data secara argumentasi berdasarkan data-data dan menganalisis data secara statistik dengan menggunakan analisis regresi sederhana yaitu untuk mengukur pengaruh antara variabel $\mathrm{X}$ terhadap variabel $Y$ dan proses perhitungan datanya menggunakan program SPSS versi 17.0.

Dari hasil analisis di atas yang pertama penulis melakukan pengujian signifikan atau uji parsial antara bauran promosi terhadap peningkatan jumlah jamaah, pengujian ini dilakukan untuk mengetahui pengaruh bauran promosi terhadap peningkatan jumlah jamaah umrah di PT. Arminareka Perdana Perwakilan Pekanbaru. Dari pengujian tersebut dapat diketahui terdapat pengaruh yang singnifikan antara bauran promosi terhadap peningkatan jumlah jamaah umroh di PT. Arminareka Perdana Perwakilan Pekanbaru, ini diketahui nilai $t_{\text {hitung }}(25,071)$ lebih besar dari nilai $t_{\text {tabel }}$ (1,661). Berarti secara parsial dapat diketahui bahwa variabel $\mathrm{X}$ (Bauran Promosi) berpengaruh terhadap variabel $Y$ (Peningkatan JumlahJamaah Umroh).

Selanjutnya penulis melakukan pengujian koefisien korelasi, dimana koefisien korelasi merupakan bentuk lain yang digunakan untuk menentukan jenis korelasi (hubungan) antara bauran promosi terhadap peningkatan jumlah jamaah umroh. Berdasarakan hasil perhitungan di atas diketahui bahwa besarnya koefisien korelasi bauran promosi terhadap peningkatan jumlah jamaah (R) sebesar $93,3 \%$, ini merupakan hubungan antara bauran promosi terhadap peningkatan jumlah jamaah umroh di PT. Arminareka Perdana Perwakilan Pekanbaru termasuk dalam kategori hubungan yang kuat atau tinggi.

Analisis yang terakhir dilakukan oleh penulis adalah analisis koefisien determinasi, dimana koefisien determinasi merupakan besaran yang menunjukkan seberapa besar kontribusi pengaruh variabel $X$ (bauran promosi) terhadap variabel Y (peningkatan jumlah jamaah). Dari hasil analisis diketahui besarnya nilai kontribusi antara bauran promosi terhadap peningkatan jumlah jamaah umroh sebesar variabel $X$ (bauran promosi) memiliki pengaruh $87 \%$ terhadap variabel $Y$ (peningkatan jumlah jamaah umrah) dan 13\% lainnya dipengaruhi oleh faktor-faktor lain diluar variabel X yaitu Produk, Harga, Tempat, Orang, dan Proses yang merupakan bagian dari Bauran Pemasaran yang tidak dimasukkan dalam penelitian ini.

\section{SIMPULAN}

Berdasarkan dari hasil pembahasan yang telah diuraikan pada bab-bab sebelumnya maka penulis dapat menyusun beberapa kesimpulan sebagai berikut :

Berdasarkan uji parsial, terdapat pengaruh yang signifikan antara promosi terhadap peningkatan jumlah jamaah umroh pada PT. Arminareka Perdana Perwakilan Pekanbaru.

Berdasarkan uji koefesien korelasi, 
dinyatakan hubungan promosi terhadap peningkatan jumlah jamaah umroh pada PT. Arminareka Perdana Perwakilan Pekanbaru sangat tinggi. Pengaruh promosi terhadap peningkatan jumlah jamaah berpengaruh besar, sedangkan sisanya dipengaruhi oleh faktor lain.

\section{DAFTAR RUJUKAN}

Al-Qur'an dan Terjemahannya, (2008). Semarang: Toha Putra

Abdullah Muhammad Bin Idris, (2013) Ringkasan Kitab Al Umm, Jakarta: Pustaka Azzam

Agus Hermawan, (2012) Komunikasi Pemasaran, Jakarta: Erlangga

Anwar Sanusi,(2011) Metodologi Penelitian Bisnis, Malang: Salemba Empat

Departemen Agama RI, (2010) DirjenBimas Islam dan Urusan Haji, Ketentuan Umum tentang Haji danUmrah, Jakarta

Freddy Rangkuti, 2009 Strategi Promosi yang Kreatif dan Analisis Kasus Intergrated Marketing Comunikation, Jakarta: PT. Gramedia Pusstaka Persada

Hartono, (2006). Statistik Untuk Penelitian, Yogyakarta: PustakaPelajar Offset

M Suyanto, (2008) Muhammad Busines Strategi and Ethics, Yogyakarta:Andi

Morrisan, (2010) Periklanan Komunikasi Pemasaran Terpadu,Jakarta: Kencana

Nembah F. HartimbulGinting, 2011) Manajemen Pemasaran, Bandung: Cv Yrama Widy

Rambat Lupiyoadi, (2011) Manajemen Pemasaran Jasa, Jakarta:Salemba Empat

Ridwan, (2011) MetodePenelitian, Jakarta: Rajawali Pers

Siti Maryam dkk, (2012) SejarahPeradaban Islam, Dari MasaKlasikHingga Modern.

Cet-1, Yogyakarta: LESFI
SyofianSiregar, (2012) Metode Penelitian Kuantitatif, Jakarta:Kencana 